\title{
Predicting patients' arrival to the Emergency Department UKMMC
}

\author{
Noriza Majid ${ }^{1 *}$, Sharifa Ezat WP2 , Saperi Sulong ${ }^{2}$, Zuraidah Che Man ${ }^{3}$ \\ From The 6th International Casemix Conference 2012 (6ICMC2012) \\ Kuala Lumpur, Malaysia. 6-7 June 2012
}

\section{Objectives}

To model and predict daily patients' arrival to the Emergency Department (ED) based on preceding year data using parametric fitting methods.

\section{Methods}

Daily patients' arrival starting from the year of 2005 to 2009 to the ED of UKM Medical Centre was studied. The patients' arrival patterns were described. Poisson and Negative Binomial models that are commonly used in modeling frequency were selected to represent the number of patient seeking treatment at ED per day. Maximum likelihood method is used in estimating the parameters for both distributions. Models accuracy were assessed by comparing the predicted arrivals that obtained from the proposed models and observed arrival using goodness of fit test.

\section{Results}

The best model to predict the patients' arrival to the ED is based on the results of p-p plots, the Schwarz-Bayesian criteria, the maximum likelihood function and chi-squared test. Results from the analysis shows that for five consecutive years, the patients' arrival to the ED at UKM Medical Centre follows the Negative Binomial distribution with an average of 192 patients a day.

\section{Conclusion}

This study confirms that the number of arrival of the patients explains the daily demand for the A\&E services. It is very important for the department to understand the pattern of patients' arrival in order to help the hospital strategize and optimize its resources.

\footnotetext{
* Correspondence: nm@ukm.my

'School of Mathematical Sciences, Faculty of Science and Technology, UKM, Selangor, Malaysia
}

Full list of author information is available at the end of the article
Author details

'School of Mathematical Sciences, Faculty of Science and Technology, UKM Selangor, Malaysia. ${ }^{2}$ Department of Community Health, Faculty of Medical, UKM, Kuala Lumpur, Malaysia. ${ }^{3}$ Department of Accident and Emergency, Faculty of Medical, UKM, Kuala Lumpur, Malaysia.

Published: 21 November 2012

doi:10.1186/1472-6963-12-S1-P5

Cite this article as: Majid et al:: Predicting patients' arrival to the Emergency Department UKMMC. BMC Health Services Research 2012 12(Suppl 1):P5.
Submit your next manuscript to BioMed Central and take full advantage of:

- Convenient online submission

- Thorough peer review

- No space constraints or color figure charges

- Immediate publication on acceptance

- Inclusion in PubMed, CAS, Scopus and Google Scholar

- Research which is freely available for redistribution

Submit your manuscript at www.biomedcentral.com/submit
C Biomed Central

\section{Biomed Central}

(c) 2012 Majid et al; licensee BioMed Central Ltd. This is an Open Access article distributed under the terms of the Creative Commons Attribution License (http://creativecommons.org/licenses/by/2.0), which permits unrestricted use, distribution, and reproduction in any medium, provided the original work is properly cited. 